\title{
THE STABILITY AND PREDICTIVE POWER OF FINANCIAL LITERACY: EVIDENCE FROM LONGITUDINAL DATA
}

\author{
Marco Angrisani \\ Jeremy Burke \\ Annamaria Lusardi \\ Gary Mottola \\ Working Paper 28125 \\ http://www.nber.org/papers/w28125 \\ NATIONAL BUREAU OF ECONOMIC RESEARCH \\ 1050 Massachusetts Avenue \\ Cambridge, MA 02138 \\ November 2020
}

We would like to thank Gerri Walsh and participants to the CIPHER2020 conference for many helpful suggestions and comments. We also acknowledge financial support from the FINRA Foundation. All errors are our responsibility. The views expressed herein are those of the author and do not necessarily reflect the views of the National Bureau of Economic Research.

NBER working papers are circulated for discussion and comment purposes. They have not been peer-reviewed or been subject to the review by the NBER Board of Directors that accompanies official NBER publications.

(C) 2020 by Marco Angrisani, Jeremy Burke, Annamaria Lusardi, and Gary Mottola. All rights reserved. Short sections of text, not to exceed two paragraphs, may be quoted without explicit permission provided that full credit, including (C) notice, is given to the source. 
The Stability and Predictive Power of Financial Literacy: Evidence from Longitudinal Data Marco Angrisani, Jeremy Burke, Annamaria Lusardi, and Gary Mottola

NBER Working Paper No. 28125

November 2020

JEL No. D14,G51,G53

\begin{abstract}
$\underline{\text { ABSTRACT }}$
We administered the FINRA Foundation's National Financial Capability Study questionnaire to members of the RAND American Life Panel (ALP) in 2012 and 2018. Using this unique, longitudinal data set, we investigate the evolution of financial literacy over time and shed light on the causal effect of financial knowledge on financial outcomes. Over a six-year observation period, financial literacy appears to be rather stable, with a slight tendency to decline at older ages. Moreover and importantly, financial literacy has significant predictive power for future financial outcomes, even after controlling for baseline outcomes and a wide set of demographics and individual characteristics that influence financial decision making. This estimated relationship is significantly stronger for older individuals, for women, and for those with lower income than for their counterparts in the study. Altogether, our findings suggest that differences in the stock of financial knowledge may lead to increasing inequality over the life course.
\end{abstract}

Marco Angrisani

Center for Economic and Social Research

and Department of Economics

University of Southern California

635 Downey Way

Los Angeles, CA 90089

angrisan@usc.edu

Jeremy Burke

University of Southern California

Center for Economic and

Social Research (CESR)

1909 K St NW, Suite 530

Washington, DC 20006-1101

jeremyburke1@gmail.com
Annamaria Lusardi

The George Washington University

School of Business

2201 G Street, NW

Duques Hall, Suite 450E

Washington, DC 20052

and NBER

alusardi@gwu.edu

Gary Mottola

Financial Industry Regulatory Authority

1735 K Street, NW

Washington, DC 20006

gary.mottola@finra.org 


\section{Introduction}

In most developed economies, changes in Social Security pension benefits and public health provisions and the shift from defined-benefit to defined-contribution private pension plans have placed more saving and investment responsibility on households. As a result, individuals have been confronted with increasingly complex financial planning and decisions, while having to navigate a financial landscape of sophisticated products. In such a scenario, it is crucial to know how well-equipped individuals are to deal with complicated financial decisions, how this capability differs across groups in the population, and how people can be helped to make good choices.

Academics and others are interested in acquiring this information, which requires reliable measures of individuals' financial knowledge. Pioneering work by Lusardi and Mitchell (2008, 2011aa) has defined a standard approach to measuring financial literacy. In the United States, financial literacy assessment questions have been administered in a number of national surveys: the Health and Retirement Study (Lusardi and Mitchell, 2011a), the National Longitudinal Survey of Youth (Lusardi et al., 2010), the National Financial Capability Study (Lusardi and Mitchell, 2011), the RAND American Life Panel (Angrisani et al., 2016), and the Understanding America Study (Angrisani and Casanova, 2019). National surveys in more than 15 countries have also used the original Big Three financial literacy questions, designed by Lusardi and Mitchell, and an international survey has collected similar financial literacy information in more than 140 countries (Klapper and Lusardi, 2020).

The available financial literacy measures reveal worrisomely low levels of financial knowledge in the U.S. population at large, with substantial heterogeneity by age, sex, and education (Lusardi and Mitchell, 2014). Importantly, these measures have been shown to correlate strongly with financial behaviors and outcomes. While a substantial amount of work has examined contemporaneous correlations, very little research has investigated how financial literacy changes over time and predicts financial outcomes. We contribute to the literature in three important ways. First, we collect longitudinal data and document how financial literacy evolves over time. Given the paucity of panel data, this is an important and novel contribution and speaks to the quality of the financial literacy data. We are the first to show the stability of financial literacy over time. Second, we link financial literacy to future financial outcomes in a way that overcomes the reverse 
causality concerns affecting much of the existing empirical work. Third, we are able to control for a wide range of individual characteristics related to financial knowledge and outcomes that, if omitted, could bias estimates, and to explore heterogeneous effects of financial literacy on financial outcomes by demographics, such as gender, age, and income. It is important to do so, given the many differences observed in micro data across segments of the population.

The identification and estimation of the causal effect of financial literacy on financial outcomes pose important empirical challenges. Individual traits, abilities, and circumstances may impact the likelihood of financial skill acquisition. At the same time, it is plausible to think that these traits and abilities directly affect financial outcomes. Because of this, it is likely that crosssectional estimates of the effect of financial literacy on financial outcomes suffer from omitted variable bias. The availability of repeated observations on individuals' financial literacy score and financial outcomes permits accounting for this heterogeneity through fixed-effects regressions. However, fixed-effects estimates may still be biased due to reverse causality: Individuals with higher wealth may have more opportunity and more incentives to acquire financial skills. This, in turn, may increase their wealth (Lusardi, Michaud, and Mitchell, 2017). Such a mechanism makes it hard to disentangle cause from effect.

In this paper, we examine changes in individuals' financial literacy and outcomes over time. For this purpose, we rely on two waves of the FINRA Foundation's National Financial Capability Study (NFCS), which we administered as part of the ALP in 2012 and 2018 to a sample of about 1,500 panel members representative of the U.S. adult population. ${ }^{2}$ Repeated observations on the same individuals approximately six years apart allow us to analyze how financial knowledge evolves over time and how levels of financial literacy influence future financial behaviors. Since an individual's financial outcomes in 2018 cannot affect his/her level of financial knowledge in 2012, we can circumvent the reverse causality problem, which, as mentioned above, would potentially bias both cross-sectional and fixed-effects estimates. At the same time, the richness of our data allows us to control for many individual traits and characteristics that may drive financial knowledge and financial outcomes, thereby reducing biases from omitted variables. Thus, with

\footnotetext{
${ }^{2}$ We have specialized knowledge on these surveys, having designed many of the questions, including the financial literacy questions, for both the NFCS and the ALP.
} 
reasonable confidence, we can interpret any observed, significant relationship between financial literacy and financial outcomes as evidence of a causal effect of the former on the latter.

Panel surveys on financial literacy are rare. This paper represents one of the few attempts to collect and analyze longitudinal data on financial literacy and financial outcomes, and one of the first to do so with U.S. data. ${ }^{3}$ Because the NFCS questionnaire provides comparable measures of individuals' financial knowledge and financial behavior, we are able to offer further insights into what shapes household saving and planning, with a specific focus on the role that financial literacy plays in financial decisions and outcomes. While many studies find a positive relationship between financial literacy and financial outcomes in cross-sectional data (Lusardi and Mitchell, 2014), it is largely unknown whether the gap in financial outcomes between those with low and high financial literacy widens or narrows over time. Such knowledge is crucial for devising and implementing programs that can effectively improve financial decision making and financial wellbeing of households, particularly among those for whom resources are relatively scarce and/or financial decisions are affected by psychological and other hurdles. ${ }^{4}$

Our data show limited within-individual variation in financial literacy over our six-year window of analysis. On a $0-5$ scale, the average level of financial literacy in the panel is 3.53 in 2012 (wave 1) and 3.42 in 2018 (wave 2). Approximately half of the sample have the same financial literacy score in both waves, and for about 90\% of study participants, the score in 2018 is within one point of that in 2012. The correlation between financial literacy in 2012 and 2018 is about $70 \%{ }^{5}$ This is a novel finding, indicating that financial literacy may be a rather fixed trait in both young and middle-aged adults. The slight decline in financial literacy score observed in the panel is mainly driven by individuals over the age of 65, a fact that may reflect cognitive aging, which has been shown to affect the level of financial literacy (Finke et al., 2017), financial

\footnotetext{
${ }^{3}$ Alessie, Lusardi, and van Rooij (2011) use longitudinal data on financial knowledge drawn from the Dutch CentERPanel, though limit analysis to effects on retirement planning.

${ }^{4}$ In the context of India, Carpena et al. (2019) find that the link between a higher level of financial literacy and better financial outcomes is significantly stronger when financial education is accompanied with short-term achievable and non-binding financial goals, as well as with financial counseling.

${ }^{5}$ Our results differ somewhat from Schmeiser and Seligman (2013), who find that individuals' answers to financial literacy questions exhibit a great degree of inconsistency over time and that good performance in a financial literacy quiz has little predictive power for future asset holdings. However, Schmeiser and Seligman (2013) focus on a set of three questions that are unlikely to adequately capture financial literacy: two of the questions measure numeracy and familiarity with probabilities and only one assesses understanding of interest compounding.
} 
decision-making capability more generally (Gamble et al., 2015), and actual financial outcomes (Angrisani and Lee, 2019).

We regress 2018 financial outcome variables, all of which proxy for different dimensions of financial well-being, on the level of financial literacy observed in 2012. We find that financial literacy has significant predictive power for a set of future outcomes, including household satisfaction with finances, ability to meet unexpected financial needs, and planning for retirement, even after controlling for baseline outcomes. Thus, financial literacy matters for financial decision making and financial security in both the short and medium term.

We also analyze how the relationship between financial literacy and future outcomes varies across distinct demographic groups. This reveals important heterogeneity, with financial literacy affecting financial outcomes relatively more for older individuals, for women and for those with lower income. In view of the strong contemporaneous correlation between financial literacy and financial outcomes found in previous studies, our results indicate not only that individuals with higher financial literacy have better current financial well-being but also that their well-being will differentially improve in the future. Since we find that financial literacy is relatively stable at young and middle ages, our findings suggest that differences in the relatively fixed stock of financial knowledge contribute to increasing disparities in financial outcomes over the life cycle.

The remainder of the paper proceeds as follows. Section 2 briefly describes the data used for this study. Section 3 documents the evolution of financial literacy over time in the whole sample and separately by age and cognitive ability. Section 4 investigates the extent to which financial literacy is predictive of future financial outcomes, while Section 5 explores heterogeneity in this relationship across distinct demographic groups. Section 6 concludes.

\section{Data}

Our data come from two waves of the FINRA Foundation's National Financial Capability Study (NFCS) fielded as part of the RAND ALP, which is a probability based, nationally representative online panel of U.S. adults age 18 and above. The first wave was fielded in 2012 to a sample of about 2,000 adults. In July 2018, we invited the 1,455 active ALP members who had answered the

2012 NFCS questionnaire to retake the survey. Of these respondents, 1,232 started the survey and 
1,170 completed it. In the analyses that follow, we include respondents who participated in both waves, even if they did not finish the survey, as long as they have a financial literacy score. ${ }^{6}$ The final sample includes 1,197 individuals and 2,394 individual-time observations. ${ }^{7}$ The summary statistics for the main demographic variables in the panel at baseline (in 2012) are shown in Table 1 below. An analysis of sample attrition, provided in the Appendix, shows that the probability of participating in the second wave of the NFCS ALP is relatively higher for Whites, middle-aged and older individuals, those with at least a Bachelor's degree, and with annual household incomes greater than $\$ 60,000$ in 2012 (these demographic characteristics will be controlled for in our regression analysis).

Table 1: Sample Characteristics in 2012

\begin{tabular}{lc}
\hline & Wave 1 \\
\hline Age & 50.47 \\
Female & 0.58 \\
White & 0.73 \\
Married & 0.63 \\
Education & \\
$\quad$ High school or less & 0.18 \\
$\quad$ Some college & 0.35 \\
$\quad$ Bachelor's or more & 0.47 \\
Household Income & \\
$\quad$ \$30,000 & 0.23 \\
$\quad$ \$30,000 - \$59,999 & 0.31 \\
$\quad \$ 60,000-\$ 99,999$ & 0.25 \\
$\quad \$ 100,000+$ & 0.21 \\
\hline$N$ & 1,197 \\
\hline
\end{tabular}

Individuals who participated in both NFCS ALP waves are also older, more educated, and with higher incomes than the population at large. ${ }^{8}$ In our 2012 sample, average age is about 50, versus 47 in the population; the proportion of female respondents is $58 \%$, versus $51 \%$ in the population; and the proportion of White respondents is $73 \%$, versus $67 \%$ in the population. Nearly half the

\footnotetext{
${ }^{6}$ When referencing findings throughout the paper, we use the term "current" to refer to data and statistics from our baseline assessment (i.e., 2012) and "future" to refer to data and statistics from our end-line assessment (i.e., 2018).

${ }^{7}$ The number of observations will vary slightly across regressions depending on the outcome variables and the covariates used in the model.

${ }^{8}$ Population benchmarks are obtained from the Current Population Survey, Annual Social and Economic Supplement of March 2012.
} 
sample has a college degree; in the general population, this fraction is $30 \%$. Our sample is more closely representative of the population in terms of household income, with $54 \%$ of our sample from households earning less than $\$ 60,000$, versus $57 \%$ in the population at large. These documented differences are consistent with the changes in the composition of the ALP population over time, with younger, less educated, and less affluent respondents having shown higher attrition and non-response rates. Over the six-year time span covered by our two waves of data, there are no significant changes in the demographics shown in Table 1 (most of which are constant by definition), except for a mechanical increase in age and a slight increase in household income.

\section{The Stability of Financial Literacy}

In both waves, respondents were administered a set of five financial literacy questions covering fundamental economics and finance concepts. These questions have become known as the Big Five (Hastings, Madrian, and Skimmyhorn, 2013) and are one of several commonly used financial literacy measures. The Big Five consist of three multiple choice questions assessing aptitude with simple interest calculations (related to savings accounts and inflation) and understanding of the relationship between interest rates and bond prices and two true/false questions testing individuals' knowledge of the relationship between the length of a mortgage and the overall interest paid over the life of the loan and the concept of risk diversification (Lusardi and Mitchell, 2014). The exact wording of the questions is reported in Appendix B. We construct a financial literacy index by summing the correct responses to the financial literacy questions.

Over our six-year analysis timeframe, we find that financial literacy declines slightly in aggregate, though remains quite stable overall. Differences between the proportion of correct responses across survey waves are muted, with the largest difference being a five percentage point decline in the fraction correctly answering the risk diversification question ( $p$-value $=0.01$, other differences between correct responses are not statistically significant). Reduced correct responses are largely driven by an increase in "don't know" responses. For all but the interest rate questions, there were fewer incorrect responses in 2018 than 2012 (Table 2). ${ }^{9}$

\footnotetext{
${ }^{9}$ There is also a decline in financial literacy in the 2018 versus the 2012 wave of the NFCS, although the data is crosssectional and does not follow the same individuals over time.
} 
Figure 1 highlights the distribution of financial literacy scores (number of correct answers) across the two waves. The average financial literacy level in 2012 is 3.53, and it drops slightly to 3.43 in 2018. Using a paired sample t-test, we reject the null that the average difference across waves is zero at any conventional significance level ( $p$-value $=0.000)$. There is little difference in the proportion of respondents answering all questions correctly across the two years, though a general leftward shift of the distribution between 2012 and 2018 for scores below five is observed. Nearly half of the respondents (48\%) have the same score in 2018 as in 2012, and 87\% have a score in 2018 that is within one point of their score in 2012.

Table 2: Fraction of Correct Responses across Waves

\begin{tabular}{|c|c|c|c|c|}
\hline & \multicolumn{2}{|c|}{2012} & \multicolumn{2}{c|}{2018} \\
\hline & Correct & Don't know & Correct & Don't know \\
\hline Interest rate question & $88 \%$ & $6 \%$ & $86 \%$ & $6 \%$ \\
\hline Inflation question & $76 \%$ & $10 \%$ & $76 \%$ & $11 \%$ \\
\hline Bond price question & $36 \%$ & $41 \%$ & $35 \%$ & $44 \%$ \\
\hline Mortgage question & $86 \%$ & $7 \%$ & $84 \%$ & $10 \%$ \\
\hline Risk diversification question & $67 \%$ & $27 \%$ & $62 \%$ & $33 \%$ \\
\hline
\end{tabular}




\section{Figure 1: Distribution of Financial Literacy across Years}

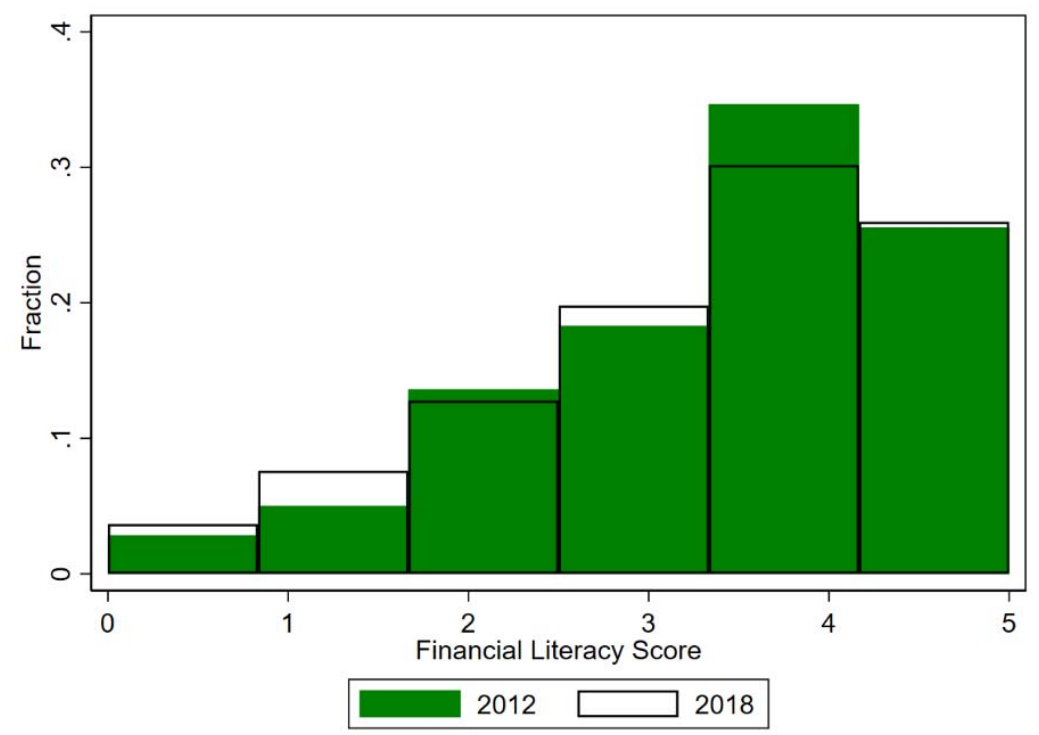

The slight decline in average financial literacy between the two survey waves is driven primarily by reduced financial literacy among older adults. Table 3 documents the mean difference in financial literacy score between waves by age/cohort. On average, financial literacy decreased over the six-year observation period for all cohorts, with the largest, and only statistically significant, decline (using a paired-sample t-test) occurring among adults above the age of 65. This is consistent with cross-sectional evidence suggesting that financial literacy declines late in life, and that the decline may be driven in part by cognitive aging (Finke et al., 2017).

Table 3: Change in Financial Literacy by Age Cohort

\begin{tabular}{|c|c|}
\hline Age Cohort & $\begin{array}{c}\text { Change in } \\
\text { Financial Literacy }\end{array}$ \\
\hline $18-34$ & -0.014 \\
\hline $35-44$ & $-0.159^{*}$ \\
\hline $45-54$ & -0.046 \\
\hline $55-64$ & -0.144 \\
\hline 65 and older & $-0.165^{* * *}$ \\
\hline Notes: ${ }^{* *} \mathrm{p}<0.01, * * \mathrm{p}<0.05, * \mathrm{p}<0.10$ \\
\hline
\end{tabular}


We have information on cognition from the ALP, but only at one point in time, elicited between September 2012 and May 2013 for all participants. That information is in the form of test scores on a series of computer-adaptive cognitive tests, which we aggregate in a comprehensive cognition index by summing scores across all tests (we standardize this index to have mean 0 and standard deviation 1 in the sample). ${ }^{10}$ We then assign respondents to four groups corresponding to the quartiles of the index distribution in the sample. As can be seen in Table 4, we find a relationship between cognition and future decline in financial literacy. Individuals in the bottom three cognitive ability quartiles all experience slight declines in financial literacy, with the largest decline experienced by those with the lowest cognition. Those in the highest cognitive ability quartile have financial literacy scores that remain relatively unchanged across the survey waves. ${ }^{11}$

Table 4: Change in Financial Literacy by Cognition

\begin{tabular}{|c|c|}
\hline Cognitive Quartile & $\begin{array}{c}\text { Change in } \\
\text { Financial Literacy }\end{array}$ \\
\hline $1^{\text {st }}$ & $-0.193^{* *}$ \\
\hline $2^{\text {nd }}$ & $-0.111^{*}$ \\
\hline $3^{\text {rd }}$ & $-0.163 * * *$ \\
\hline \multicolumn{2}{|c|}{$4^{\text {th }}$} \\
\hline \multicolumn{2}{|c|}{ Notes: ${ }^{* *} p<0.01, * * p<0.05, * p<0.10$} \\
\hline
\end{tabular}

\section{Financial Literacy and Future Financial Outcomes}

In addition to measuring changes over time, a key feature of our longitudinal data is that they allow us to examine the predictive power of financial literacy many years into the future. The question we explore is: Controlling for observable characteristics, individual-specific traits, and current financial outcomes, does financial literacy predict future financial outcomes? The NFCS ALP

\footnotetext{
${ }^{10}$ The available tests are (i) the number series test, in which respondents are given a sequence of numbers with a blank somewhere in the sequence and asked to provide the missing value; (ii) the verbal analogies test, in which respondents are shown words that make up an analogy and, based on this relationship, are asked to fill in a missing word in a second analogy; (iii) the picture vocabulary test, in which respondents are shown pictures and asked to name the object they see; (iv) the abstract reasoning test, in which respondents are asked to solve various problems involving abstract reasoning; and (v) the antonyms test, in which respondents are shown a word and asked to type another with the opposite meaning.

${ }^{11}$ Wilson et al. (2016) find a positive relationship between financial and health literacy and cognitive health in a sample of older Americans.
} 
elicits a range of variables that can proxy for financial well-being, from subjective satisfaction with current financial situation to the capacity to face a shock, as well as variables that capture aspects of financial capability, such as retirement planning and credit/debt management. We divide these variables into positive and negative financial outcomes. The positive set includes satisfaction with overall financial situation, measured on a 10-point scale; lack or low level of financial fragility, measured by one's confidence in their ability to come up with $\$ 2,000$ if an unexpected need arose within a month; and an indicator that respondents have (ever) tried to figure out how much they need to save for their retirement, which is known to be a strong predictor of wealth accumulation (Lusardi and Mitchell, 2007). Among the negative or detrimental outcomes, we consider whether respondents report having too much debt, whether they have used alternative financial services (payday loans, pawn shops, tax-refund loans, car title loans, and rent-to-own shops) in the past five years, and whether they use credit cards in an expensive way (paying the minimum only, making a late payment, going over the limit, or using the card for a cash advance). All of these latter measures capture, to a varying degree, financial distress and difficulties with personal finances.

We perform OLS regressions using each of these outcomes in 2018 as dependent variables and financial literacy as observed in 2012 as the main explanatory variable of interest. Other regressors include demographic characteristics measured in 2012 (gender, race, age, marital status, education, income, and labor force status); a composite index score for cognitive ability preferences and individual traits, namely aversion to risk and attitude toward planning; and the dependent variable itself measured at baseline (in 2012). ${ }^{12}$ We use two specifications, a parsimonious one, which only includes demographics and the lagged dependent variable, and one that accounts for individual attitudes and preferences. The estimated relationship between financial literacy and future financial outcomes is reported in Tables 5 and 6 . To ensure that the sample size remains the same across specifications, we exclude from the analysis respondents with missing values of either the dependent variable or any of the explanatory variables used in the regressions. Due to skip patterns within the questionnaire, information about retirement planning and credit

12 Attitude toward planning is elicited by asking respondents to express, using a 5-point scale, their agreement/disagreement with the statement "Before going on a vacation, I spend a great deal of time examining where I would most like to go and what I would like to do." See Ameriks, Caplin, and Leahy (2003). This variable, which can plausibly be thought of as a time-invariant individual trait, was elicited in 2018 but not in 2012. 
card use is available for only about $80 \%$ of the original sample. Hence, the regressions featuring these two outcomes as dependent variable show a reduced sample size.

Overall, we find that financial literacy has significant predictive power for future financial outcomes, even after controlling for current outcomes, a wide set of demographics, and individualspecific traits. Specifically, those who have higher financial literacy are more likely to be satisfied with their financial situation, more likely to be able to face a mid-size shock, and more likely to plan for retirement in the future. Estimates are sizeable. For example, a one-unit increase in the 2012 financial literacy index is associated with a 0.13-point increase in financial satisfaction in 2018. This corresponds to an almost $2.5 \%$ increase relative to mean financial satisfaction in the sample (about 6 on a 10-point scale). Thus, the effect is not only statistically significant but also economically meaningful. Similarly, individuals with higher financial literacy are about 5 percentage points more likely to be able to meet an unexpected $\$ 2,000$ shock, representing a sizeable $8 \%$ increase relative to a sample proportion of $61 \%$, consistent with the findings of Hasler, Lusardi, and Oggero (2018). Finally, answering one more financial literacy question correctly in 2012 is associated with about a 3.5 percentage-point increase in the likelihood of having done any retirement planning in 2018 , a $6 \%$ positive change from a sample proportion of $57 \%$.

On the other hand, we find little effect of financial literacy on negative financial behavior, mostly related to debt and debt management. This suggests that poor financial decision making may be driven by factors like shocks and resource scarcity and not as much by lack of financial knowledge. In view of previous research, there exists evidence that, irrespective of financial literacy, the majority of people recognize that carrying a lot of debt, not making credit card payments on time, or using alternative financial services (which tend to charge high interest rates and fees) have negative consequences. Failure to avoid these behaviors is more plausibly driven by behavioral factors (e.g., present bias), resource constraints, and financial shocks than by lack of financial knowledge. ${ }^{13}$

\footnotetext{
${ }^{13}$ As shown in several papers, people with lower financial literacy can and do make mistakes about debt (see for example Agarwal, Rosen, and Yao [2015]). Other papers show a link between financial literacy and debt (see a summary in Lusardi and Mitchell (2014), but our variables are more geared toward measuring financial distress.
} 
Table 5: Predictive Power of Financial Literacy for Future Outcomes (I)

\begin{tabular}{|c|c|c|c|c|c|c|}
\hline \multirow[b]{2}{*}{ Explanatory Variables } & \multicolumn{2}{|c|}{\begin{tabular}{|c|} 
Financially Satisfied \\
in 2018 \\
\end{tabular}} & \multicolumn{2}{|c|}{$\begin{array}{c}\text { Can Meet } \$ 2,000 \\
\text { Shock in } 2018 \\
\end{array}$} & \multicolumn{2}{|c|}{$\begin{array}{c}\text { Retirement Planning } \\
\text { in } 2018 \\
\end{array}$} \\
\hline & (1) & (2) & (1) & (2) & (1) & (2) \\
\hline Financi & $\begin{array}{l}0.135 * * \\
(0.067)\end{array}$ & $\begin{array}{l}0.131 * * \\
(0.067)\end{array}$ & $\begin{array}{c}0.047 * * * \\
(0.012)\end{array}$ & $\begin{array}{c}0.047 * * * \\
(0.012)\end{array}$ & $\begin{array}{l}0.036 * * \\
(0.017)\end{array}$ & $\begin{array}{l}0.032 * \\
(0.017)\end{array}$ \\
\hline Demographics & $\mathrm{x}$ & $X$ & $\mathrm{x}$ & $\mathrm{x}$ & $\mathrm{x}$ & $\mathrm{x}$ \\
\hline Cognitive ability & $\mathrm{x}$ & $X$ & $\mathrm{x}$ & $\mathrm{x}$ & $\mathrm{x}$ & $X$ \\
\hline Risk aversion & & $\mathrm{X}$ & & $\mathrm{x}$ & & $\mathrm{x}$ \\
\hline Planning attitude & & $\mathrm{X}$ & & $\mathrm{x}$ & & $\mathrm{X}$ \\
\hline Dep. Variable in 2012 & $\begin{array}{c}0.481 * * * \\
(0.030)\end{array}$ & $\begin{array}{c}0.478 * * * \\
(0.030)\end{array}$ & $\begin{array}{c}0.366^{* * *} \\
(0.031)\end{array}$ & $\begin{array}{c}0.365 * * * \\
(0.031)\end{array}$ & $\begin{array}{l}0.405 * * * \\
(0.034)\end{array}$ & $\begin{array}{c}0.394 * * * \\
(0.035)\end{array}$ \\
\hline Observations & 1,094 & 1,094 & 1,094 & 1,094 & 848 & 848 \\
\hline R-squared & 0.391 & 0.391 & 0.393 & 0.394 & 0.304 & 0.310 \\
\hline
\end{tabular}

Demographics include gender, race, age, education, marital status, labor force status, and income. All explanatory variables are measured in 2012, except risk aversion and planning attitude, which are treated as constant individual traits. The full set of estimated coefficients is reported in Table A3 in Appendix C. Robust standard errors in parentheses $* * * \mathrm{p}<0.01, * * \mathrm{p}<0.05, * \mathrm{p}<0.1$.

In the interest of space and since our focus is on financial literacy, we will comment on just a few other estimated coefficients (the complete set of estimated coefficients is provided in Appendix C): Financial outcomes do not vary significantly by gender, with the exception of use of alternative financial services, which is less likely among women, but outcomes are very different by race, with White respondents faring much better than minorities. As might be expected, financial outcomes are generally better for those with higher income, higher education, and higher cognitive ability (although a higher cognition score in 2012 is associated with having too much debt in 2018). Interestingly, financial outcomes are better for those who are older or retired, but risk aversion and planning attitude are not statistically significant in our regressions. 
Table 6: Predictive Power of Financial Literacy for Future Outcomes (II)

\begin{tabular}{|c|cccccc}
\hline & \multicolumn{2}{|c}{$\begin{array}{c}\text { Too Much Debt } \\
\text { in 2018 }\end{array}$} & \multicolumn{2}{c}{$\begin{array}{c}\text { Use of AFS } \\
\text { in 2018 }\end{array}$} & \multicolumn{2}{c}{$\begin{array}{c}\text { Bad Credit Card } \\
\text { Behavior in 2018 }\end{array}$} \\
\hline Explanatory Variables & $(1)$ & $(2)$ & $(1)$ & $(2)$ & $(1)$ & $(2)$ \\
\hline Financial Literacy & -0.068 & -0.078 & 0.004 & 0.005 & 0.007 & 0.006 \\
& $(0.063)$ & $(0.064)$ & $(0.011)$ & $(0.011)$ & $(0.015)$ & $(0.015)$ \\
& & & & & & \\
Demographics & $\mathrm{X}$ & $\mathrm{X}$ & $\mathrm{X}$ & $\mathrm{X}$ & $\mathrm{X}$ & $\mathrm{X}$ \\
Cognitive ability & $\mathrm{X}$ & $\mathrm{X}$ & $\mathrm{X}$ & $\mathrm{X}$ & $\mathrm{X}$ & $\mathrm{X}$ \\
Risk aversion & & $\mathrm{X}$ & & $\mathrm{X}$ & & $\mathrm{X}$ \\
Planning attitude & & $\mathrm{X}$ & & $\mathrm{X}$ & & $\mathrm{X}$ \\
& & & & & & \\
Dep. Variable in 2012 & $0.414 * * *$ & $0.416 * * *$ & $0.313 * * *$ & $0.313 * * *$ & $0.389 * * *$ & $0.386 * * *$ \\
& $(0.029)$ & $(0.029)$ & $(0.037)$ & $(0.038)$ & $(0.035)$ & $(0.035)$ \\
& & & & & & 875 \\
Observations & 1,094 & 1,094 & 1,094 & 1,094 & 875 & 875 \\
R-squared & 0.325 & 0.326 & 0.217 & 0.217 & 0.265 & 0.266 \\
\hline
\end{tabular}

Demographics include gender, race, age, education, marital status, labor force status, and income. All explanatory variables are measured in 2012, except risk aversion and planning attitude, which are treated as constant individual traits. The full set of estimated coefficients is reported in Table A4 in Appendix C. Robust standard errors in parentheses ${ }^{* * *} \mathrm{p}<0.01,{ }^{* *} \mathrm{p}<0.05,{ }^{*} \mathrm{p}<0.1$.

While our empirical approach addresses potential reverse causality from financial literacy to financial outcomes and vice versa, we are unable to rule out all possible sources of bias stemming from the omission of variables that correlate with financial knowledge and financial outcomes. However, since we take into account some the traits most relevant for individual financial decision making (e.g., attitude toward financial risk and planning and cognitive ability) in our regressions, we interpret our results as evidence of a causal link between financial literacy and financial outcomes. As noted above, considerable prior research has documented that higher levels of financial literacy are associated with higher levels of contemporaneously measured financial outcomes. ${ }^{14}$ Our finding that financial literacy is relatively fixed over our six-year observation period indicates that differences in the stock of financial knowledge lead to increasing disparities through the life cycle. Individuals with higher levels of current financial knowledge tend to have higher current and future levels of financial well-being relative to those with lower

\footnotetext{
${ }^{14}$ We find similar associations in our data in unreported regressions.
} 
current levels of financial knowledge. Thus, financial literacy may be a key driver of widening inequality.

\section{Heterogeneity in the Relationship between Financial Literacy and Future Financial Outcomes}

Next, we investigate the extent to which the observed relationship between financial literacy and future financial outcomes varies across distinct segments of the population. To do this, we use our richer specification, including as explanatory variables demographics, cognitive ability, individual-specific traits (risk aversion and planning attitude), the dependent variable and financial literacy as of 2012, and estimate it separately by gender, age (individuals younger than 55 and individuals age 55 or older in 2012), and income group (households with yearly income below $\$ 60,000$ and $\$ 60,000$ or above in 2012). In Table 7 , we report the estimated financial literacy coefficients for men and women and for the two aforementioned age and income groups, separately.

The observed positive effect of financial literacy on an individual's future satisfaction with their financial situation detected in the entire sample is mainly driven by men and by individuals age 55 and older. For these two groups, one more financial literacy question answered correctly is associated with a 0.22 -point increase in the future level of satisfaction with financial situation. While still positive, the corresponding coefficient is much smaller and not statistically different from zero for women and individuals younger than 55. Due to relatively small sample sizes, we cannot, however, reject the null that the effect of financial literacy on future financial satisfaction is the same between groups. The relationship between financial literacy and future financial satisfaction is similar for households with income below and above $\$ 60,000$ per year, but is statistically significant only for households with income below $\$ 60,000$. The link between financial literacy and future ability to meet an unexpected $\$ 2,000$ expense is rather homogenous between men and women and between age groups. On the other hand, it is substantially larger for those with income below $\$ 60,000$, for whom a higher financial literacy score increases the probability of being able to meet a $\$ 2,000$ expense by about 6 percentage points (a sizeable $14 \%$ increase from the sample proportion of $42 \%$ ), than it is for richer individuals (income greater than 
$\$ 60 \mathrm{k}$ ) for whom the estimated effect is smaller (about 3 percentage points) and not statistically significant.

Table 7: Predictive Power of Financial Literacy - Heterogeneity by Gender and Age

\begin{tabular}{|c|c|c|c|c|c|c|}
\hline & \multicolumn{6}{|c|}{ Financial Outcomes in 2018 (dependent variables) } \\
\hline $\begin{array}{c}\text { Financial } \\
\text { Literacy } \\
\text { in } 2012\end{array}$ & $\begin{array}{c}\text { Financially } \\
\text { Satisfied }\end{array}$ & $\begin{array}{c}\text { Can Meet } \\
\$ 2,000 \\
\text { Shock }\end{array}$ & $\begin{array}{c}\text { Retirement } \\
\text { Planning }\end{array}$ & $\begin{array}{c}\text { Too } \\
\text { Much } \\
\text { Debt }\end{array}$ & $\begin{array}{c}\text { Use of } \\
\text { AFS }\end{array}$ & $\begin{array}{c}\text { Bad } \\
\text { Credit } \\
\text { Card } \\
\text { Behavior }\end{array}$ \\
\hline Men & $\begin{array}{c}0.226^{*} \\
(0.119)\end{array}$ & $\begin{array}{c}0.052 * * \\
(0.022)\end{array}$ & $\begin{array}{c}0.020 \\
(0.027)\end{array}$ & $\begin{array}{c}0.051 \\
(0.112)\end{array}$ & $\begin{array}{c}0.000 \\
(0.019)\end{array}$ & $\begin{array}{c}0.002 \\
(0.026)\end{array}$ \\
\hline $\mathrm{N}$ & 461 & 461 & 392 & 461 & 461 & 384 \\
\hline Women & $\begin{array}{c}0.079 \\
(0.081)\end{array}$ & $\begin{array}{c}0.042 * * * \\
(0.015)\end{array}$ & $\begin{array}{c}0.044 * * \\
(0.022)\end{array}$ & $\begin{array}{l}-0.133 * \\
(0.079)\end{array}$ & $\begin{array}{c}0.007 \\
(0.013)\end{array}$ & $\begin{array}{c}0.008 \\
(0.019)\end{array}$ \\
\hline $\mathrm{N}$ & 633 & 633 & 456 & 633 & 633 & 491 \\
\hline Age $<55$ & $\begin{array}{c}0.066 \\
(0.086)\end{array}$ & $\begin{array}{c}0.046^{* * * *} \\
(0.016)\end{array}$ & $\begin{array}{c}0.017 \\
(0.023)\end{array}$ & $\begin{array}{l}-0.027 \\
(0.079)\end{array}$ & $\begin{array}{l}0.024 * \\
(0.014)\end{array}$ & $\begin{array}{c}0.015 \\
(0.021)\end{array}$ \\
\hline $\mathrm{N}$ & 625 & 625 & 452 & 625 & 625 & 467 \\
\hline Age $55+$ & $\begin{array}{c}0.224 * * \\
(0.109)\end{array}$ & $\begin{array}{c}0.046 * * \\
(0.019)\end{array}$ & $\begin{array}{c}0.053 * * \\
(0.026)\end{array}$ & $\begin{array}{c}-0.185^{*} \\
(0.106)\end{array}$ & $\begin{array}{c}-0.028^{*} \\
(0.016)\end{array}$ & $\begin{array}{l}-0.002 \\
(0.022)\end{array}$ \\
\hline $\mathrm{N}$ & 469 & 469 & 396 & 469 & 469 & 408 \\
\hline Income $<\$ 60 \mathrm{k}$ & $\begin{array}{l}0.146^{*} \\
(0.083)\end{array}$ & $\begin{array}{c}0.057 * * * \\
(0.015)\end{array}$ & $\begin{array}{c}0.017 \\
(0.023)\end{array}$ & $\begin{array}{c}-0.174 * * \\
(0.083)\end{array}$ & $\begin{array}{c}0.001 \\
(0.015)\end{array}$ & $\begin{array}{c}0.014 \\
(0.021)\end{array}$ \\
\hline $\mathrm{N}$ & 578 & 578 & 395 & 578 & 578 & 389 \\
\hline Income $>=\$ 60 \mathrm{k}$ & $\begin{array}{c}0.122 \\
(0.114)\end{array}$ & $\begin{array}{c}0.028 \\
(0.021)\end{array}$ & $\begin{array}{c}0.056^{* *} \\
(0.025)\end{array}$ & $\begin{array}{c}0.074 \\
(0.095)\end{array}$ & $\begin{array}{c}0.017 \\
(0.013)\end{array}$ & $\begin{array}{l}-0.010 \\
(0.023)\end{array}$ \\
\hline $\mathrm{N}$ & 516 & 516 & 453 & 516 & 516 & 486 \\
\hline
\end{tabular}

Separate regressions for men and women and for individuals below age 55 and age 55 or older are estimated. The set of controls is the same as in columns (2) of Tables 5 and 6 . Robust standard errors in parentheses $* * * \mathrm{p}<0.01, * *$ $\mathrm{p}<0.05,{ }^{*} \mathrm{p}<0.1$.

Women, individuals age 55 and older, and high-income households seem to benefit the most from better financial knowledge when it comes to retirement planning. For women, a oneunit increase in the financial literacy score in 2012 results in a 4.5 percentage point increase in the likelihood of planning for retirement (an effect significant at 5\%) compared to only a 2 percentage 
point increase for men (a non-statistically significant effect). These estimates correspond to a $9 \%$ and $3 \%$ increase from the corresponding sample proportions of $51 \%$ and $63 \%$. Similarly, the estimated 2012 financial literacy coefficients indicate an increase of nearly 5.5 percentage points in the probability of retirement planning among individuals age 55 or older (a $9 \%$ increase from the sample proportion) and of barely 2 percentage points $(3.5 \%$ increase from the sample proportion) among those younger than 55 . For individuals with income at or above $\$ 60,000$, a higher financial literacy score in 2012 is associated with a 5.6 percentage-point increase in the likelihood of having done some retirement planning by 2018 (an $8 \%$ increase from the sample proportion of $69 \%$ ); for those with income below $\$ 60,000$, the estimated increase is only 1.7 percentage points and is not statistically significant. Despite such large differences, we fail to reject the null that these effects are the same between groups due to relatively large standard errors.

Concerning negative outcomes, we find evidence of some heterogeneous effects. Consistent with most of the patterns already described, women, older, and less affluent individuals appear to benefit the most from increasing levels of financial knowledge. For women, answering one more financial literacy question correctly in 2012 results in a decrease of 0.13 points on the 1-7 scale measuring having too much debt in 2018 . This corresponds to a $4 \%$ decrease from a sample mean of 3.6. Conversely, there is little effect for men. Similarly, among individuals age 55 or older, a one-point increase in the financial literacy score in 2012 is associated with a decrease of 0.19 points on the having too much debt scale in 2018 , representing a negative $7 \%$ change from the sample mean of 2.6. For individuals younger than 55, financial literacy is not linked to future debt management. Among those with income below $\$ 60,000$, a one-unit increase in the financial literacy score in 2012 results in a decrease of 0.17 points on the having too much debt scale in 2018 , which constitutes a negative $4.5 \%$ change from the sample mean of 3.8 . Once again, because of relatively large standard errors, the effects by gender and age are not statistically different. We do reject the null that the effects of financial literacy on having too much debt are the same between income groups at the 5\% significance level. Finally, we do not find an effect of financial literacy on either use of alternative financial services or expensive credit card behavior across demographic groups, apart from when looking at distinct age groups. Overall, the estimated coefficients are similar to those in the whole sample. 
In summary, the results presented in this section point to three main findings. One, higher financial literacy benefits women more than men, which is consistent with the findings of previous work by Lusardi and Mitchell (2008). Two, a higher level of financial knowledge benefits individuals approaching retirement age more than their younger counterparts, confirming the key role that financial knowledge plays in planning for the future and accumulating wealth over the life cycle. Three, financial knowledge is more beneficial for low-income individuals, especially in the domains of satisfaction with finances, emergency savings, and debt management. Our empirical evidence highlights the importance of taking heterogeneity into account when assessing the effects of financial literacy, and of considering distinct financial behaviors and outcomes, which may be differentially affected by the level of financial knowledge. ${ }^{15}$

\section{Conclusions}

We administered the NFCS questionnaire to members of the RAND ALP in 2012 and again in 2018. As a result, we have at our disposal longitudinal, individual-level information on financial literacy and a broad set of financial outcomes, which is rarely found in other data sets. Importantly, we are able to complement this information with a rich set of socio-economic variables, cognitive ability measures, preference parameters and individual traits available in the ALP and that are known to influence both financial knowledge and behavior.

Exploiting this unique longitudinal data set, we investigate the evolution of financial literacy over a six-year period and identify the causal effects of financial knowledge on a set of financial outcomes that proxy for financial well-being. For this purpose, we regress financial outcomes as measured in 2018 on the level of financial literacy observed in 2012, controlling for baseline demographics, baseline financial outcomes, and individuals' traits. This empirical approach allows us to rule out reverse causality from financial outcomes to financial literacy, and to account for most of the individual-specific characteristics influencing financial decision making, thereby reducing bias from the omission of relevant variables. While existing studies find a positive correlation between financial literacy and financial outcomes in the cross-section, it is

\footnotetext{
${ }^{15}$ Other examples of personal finance programs targeting specific groups of the population are provided by Lusardi and Mitchell (2014) and Carlin, Jiang, and Spiller (2017)
} 
largely unknown whether the gap in financial outcomes between those with low and high financial literacy widens or narrows over time. Our study tackles this question and provides empirical evidence on this issue, which has important policy implications.

Over our relatively long (2012 to 2018) observation period, financial literacy exhibits very limited within-individual variation. It appears to be rather stable, with a slight tendency to decline at older ages only. There is good news and bad news about this finding. The good news is that the Big Five Financial Literacy questions are a robust measure of financial literacy, which remains stable over time. The bad news is that financial literacy improves very little over time. The finding also indicates that experience is not a great teacher, as levels of financial literacy are low even among older individuals, who have presumably made many financial decisions.

We find that financial literacy has significant predictive power for future financial outcomes, especially satisfaction with one's own financial situation, the ability to face shocks, and planning for retirement, even after controlling for baseline levels of these outcomes. These results, combined with the observed stability of financial literacy over time, suggest that differences in the stock of financial knowledge among individuals can lead to increasing disparities in financial wellbeing over the life course. Thus, differential levels of financial literacy may contribute to widening inequality among distinct segments of the population.

We investigate how the general relationship between financial literacy and future financial well-being varies across distinct demographic groups. We document a significantly stronger effect of financial literacy on future outcomes for older individuals than for their younger counterparts. This highlights the importance of equipping the young to make critical financial decisions so that they can continue down a path toward financial security. We also observe that women who have higher financial literacy experience better downstream financial outcomes than men. This indicates that higher levels of financial literacy for women may help close the gender gap in financial wellbeing. Similarly, we find that low-income individuals who have higher levels of financial literacy are better able to meet unexpected shocks and manage debt.

Our study represents progress toward a better understanding of the ways in which household financial behavior and financial literacy are linked. This knowledge is crucial for devising and implementing programs that can effectively improve household financial decision making and financial well-being, particularly among more disadvantaged and vulnerable groups 
in the population. Our results also suggest that financial knowledge may be an important contributor to increasing disparities over the life course. 


\section{References}

Agarwal, S., Rosen, R. and Yao, V. (2015), Why Do Borrowers Make Mortgage Refinancing Mistakes? Management Science 62 (12): 3393-3672

Alessie, R., Lusardi, A., and van Rooij, M. (2011) "Financial Literacy, Retirement Preparation and Pension Expectations in the Netherlands.” NBER Working Paper 17109.

Ameriks, J., Caplin, A., and Leahy, J. (2003) "Wealth Accumulation and the Propensity to Plan." Quarterly Journal of Economics, 118(3): 1007-1047.

Angrisani, M. and Casanova, M. (2019) "What You Think You Know Can Hurt You: Under/Over Confidence in Financial Knowledge and Preparedness for Retirement." Journal of Pension Economics and Finance doi:10.1017/S1474747219000131.

Angrisani, M. and Lee, J. (2019) "Cognitive Decline and Household Financial Decisions at Older Ages." Journal of the Economics of Ageing 13: 86-101.

Angrisani, M., Kapteyn, A., and Lusardi, A. (2016) “The National Financial Capability Study: Empirical Findings from the American Life Panel Survey." FINRA Research Paper, available at https://www.usfinancialcapability.org/downloads/NFCS_ALP_Report_Final.pdf

Carlin, B., Jiang, L., and Spiller S. (2017), Millennial-Style Learning: Search Intensity, Decision Making and Information Sharing, Management Science 64(7): 2973-3468.

Carpena, F., Cole, S., Shapiro, J., and Zia, B. (2019) "The ABCs of Financial Education: Experimental Evidence on Attitudes, Behavior, and Cognitive Biases." Management Science 65 (1): 346-369.

Financial Industry Regulatory Authority (FINRA) (2009) Financial Capability in the United States: National Survey, Executive Summary. Washington, DC, available at https://www.usfinancialcapability.org/downloads/NFCS_2009_Natl_Exec_Sum.pdf

Finke, M., Howe, J., and Huston, S. (2017) "Old Age and the Decline of Financial Literacy." Management Science 63 (1): 213-230.

Gamble, K.J., Boyle, P.A., Yu, L., and Bennett, D.A. (2015) "Aging and Financial Decision Making." Management Science 61 (11): 2549-2824. 
Hastings, J., B. Madrian and W. Skimmyhorn (2013 ), Financial Literacy, Financial Education and Economic Outcomes, Annual Review of Economics 5:347-73

Lusardi, A. and Mitchell, O.S. (2007a) "Baby Boomer Retirement Security: The Roles of Planning, Financial Literacy, and Housing Wealth.” Journal of Monetary Economics 54 (1): 205-24.

Lusardi, A. and Mitchell, O.S. (2007b) "Financial Literacy and Retirement Preparedness: Evidence and Implications for Financial Education.” Business Economics 42 (1): 35-44.

Lusardi, A. and Mitchell, O.S. (2011a) "Financial Literacy and Retirement Planning in the United States." Journal of Pension Economics and Finance 10 (4): 509-25.

Lusardi, A. and Mitchell, O.S. (2011b) "Financial Literacy around the World: an Overview." Journal of Pension Economics and Finance 10 (4): 497-508.

Lusardi, A. and Mitchell, O.S. (2014) "The Economic Importance of Financial Literacy: Theory and Evidence.” Journal of Economic Literature 52 (1): 5-44.

Lusardi, A., Michaud, P.C., and Mitchell, O.S. (2017) “Optimal Financial Knowledge and Wealth Inequality." Journal of Political Economy 125 (2): 431-77.

Schmeiser, M.D. and Seligman, J.S. (2013) "Using the Right Yardstick: Assessing Financial Literacy Measures by Way of Financial Well-Being." Journal of Consumer Affairs 42 (2): 24362.

Wilson, R., Yu, L., James, B., Bennett, D., and Boyle, P. (2017) “Association of Financial and Health Literacy with Cognitive Health in Old Age.” Aging, Neuropsychology, and Cognition 24 (2): 186-197. 


\section{Appendix A}

\section{Sample Attrition Analysis}

Table A1: Sample Attrition for the NFCS

\begin{tabular}{|c|c|c|c|}
\hline & $(1)$ & $(2)$ & (3) \\
\hline Female & $\begin{array}{c}0.027 \\
(0.019)\end{array}$ & $\begin{array}{c}0.022 \\
(0.020)\end{array}$ & $\begin{array}{c}0.024 \\
(0.020)\end{array}$ \\
\hline White & $\begin{array}{c}0.064 * * * \\
(0.020)\end{array}$ & $\begin{array}{c}0.040 * * \\
(0.020)\end{array}$ & $\begin{array}{l}0.038^{*} \\
(0.022)\end{array}$ \\
\hline Age 33-44 & $\begin{array}{c}0.101 * * * \\
(0.033)\end{array}$ & $\begin{array}{c}0.072 * * \\
(0.033)\end{array}$ & $\begin{array}{l}0.063 * \\
(0.033)\end{array}$ \\
\hline Age $35-54$ & $\begin{array}{c}0.120 * * * \\
(0.031)\end{array}$ & $\begin{array}{c}0.101 * * * \\
(0.030)\end{array}$ & $\begin{array}{c}0.089 * * * \\
(0.031)\end{array}$ \\
\hline Age 55-64 & $\begin{array}{c}0.114 * * * \\
(0.032)\end{array}$ & $\begin{array}{c}0.089 * * * \\
(0.032)\end{array}$ & $\begin{array}{c}0.075 * * \\
(0.032)\end{array}$ \\
\hline Age $65+$ & $\begin{array}{c}0.124 * * * \\
(0.043)\end{array}$ & $\begin{array}{c}0.092 * * \\
(0.043)\end{array}$ & $\begin{array}{l}0.083^{*} \\
(0.043)\end{array}$ \\
\hline Some College & $\begin{array}{c}0.038 \\
(0.027)\end{array}$ & $\begin{array}{c}0.022 \\
(0.026)\end{array}$ & $\begin{array}{c}0.042 \\
(0.027)\end{array}$ \\
\hline Bachelor's or More & $\begin{array}{c}0.078 * * * \\
(0.027)\end{array}$ & $\begin{array}{l}0.049 * \\
(0.027)\end{array}$ & $\begin{array}{c}0.062 * * \\
(0.029)\end{array}$ \\
\hline Married & $\begin{array}{l}-0.002 \\
(0.019)\end{array}$ & $\begin{array}{c}-0.011 \\
(0.019)\end{array}$ & $\begin{array}{l}-0.007 \\
(0.019)\end{array}$ \\
\hline Employed & $\begin{array}{l}-0.006 \\
(0.023)\end{array}$ & $\begin{array}{l}-0.000 \\
(0.023)\end{array}$ & $\begin{array}{c}0.001 \\
(0.023)\end{array}$ \\
\hline Retired & $\begin{array}{c}0.015 \\
(0.041)\end{array}$ & $\begin{array}{c}0.024 \\
(0.040)\end{array}$ & $\begin{array}{c}0.027 \\
(0.039)\end{array}$ \\
\hline Household Income $>\$ 60,000$ & $\begin{array}{c}0.053 * * \\
(0.022)\end{array}$ & $\begin{array}{l}0.044 * * \\
(0.021)\end{array}$ & $\begin{array}{c}0.042 * * \\
(0.021)\end{array}$ \\
\hline Financial Literacy Score & & $\begin{array}{c}0.008 \\
(0.008)\end{array}$ & $\begin{array}{c}0.009 \\
(0.009)\end{array}$ \\
\hline Cognition Score & & & $\begin{array}{l}-0.006 \\
(0.012)\end{array}$ \\
\hline Observations & 1,455 & 1,414 & 1,352 \\
\hline
\end{tabular}

Probit average marginal effects with Delta Method robust standard errors in parentheses. *** $\mathrm{p}<0.01$, ** $\mathrm{p}<0.05, * \mathrm{p}<0.1$.

The number of individuals who answered the NFCS questionnaire in 2012 and were still active ALP members in 2018 is 1,455. All these individuals were invited to re-take the NFCS 
questionnaire in 2018. Considering this pool of potential respondents, we create an indicator taking the value of 1 if the invited ALP member answered the 2018 NFCS questionnaire and 0 otherwise. We then estimate a Probit model using this indicator as a dependent variable and the following set of regressors measured in 2012: gender, age, education, marital status, labor force status, household income, financial literacy score, and cognitive ability score. Table A1 presents average marginal effects from this estimation exercise.

As can be seen, the probability of answering the second NFCS ALP wave, conditional on having answered the first, is higher among White, middle-aged, and older respondents. It is around 6 percentage points higher among individuals with a bachelor's degree or more compared to those with high school or less, and about 4 percentage points higher among households with income greater than $\$ 60,000$. In contrast, the likelihood of answering the 2018 NFCS questionnaire does not correlate with gender, marital status, labor force status, financial literacy level, or cognitive ability.

We also perform an analysis of attrition from the ALP between 2012 and 2018. Besides the 1,455 respondents who answered the NFCS questionnaire in 2012 and were still active ALP members in 2018, another 620 dropped out of the ALP by the time we administered the second wave of the NFCS. In Table A2, we estimate a Probit model for the probability of remaining an active ALP member in 2018, conditional on having participated in the NFCS in 2012. This analysis provides insights on which individual characteristics are associated with the likelihood of leaving the ALP over time and, therefore, on how the composition of the panel may have changed during the observation period of our study.

As can be seen, the probability of remaining in the ALP between 2012 and 2018 is higher for women and individuals with at least a bachelor's degree. It is significantly lower among those age 18-32 than among their older counterparts. Unlike the NFCS attrition documented above, ALP attrition is associated with financial literacy. Specifically, one more financial literacy question answered correctly in 2012 increases the chances of remaining in the panel by about 3 percentage points. There is no correlation between the probability of attrition and individuals' cognitive ability. 
Table A2: Sample Attrition for the ALP

\begin{tabular}{lccc}
\hline & $(1)$ & $(2)$ & $(3)$ \\
\hline & & & \\
Female & $0.034^{*}$ & $0.051^{* *}$ & $0.048^{* *}$ \\
White & $(0.020)$ & $(0.021)$ & $(0.021)$ \\
& -0.010 & -0.037 & $-0.062^{* *}$ \\
Age 33-44 & $(0.022)$ & $(0.024)$ & $(0.026)$ \\
& $0.116^{* * *}$ & $0.106^{* * *}$ & $0.126^{* * *}$ \\
Age 35-54 & $(0.033)$ & $(0.034)$ & $(0.035)$ \\
& $0.196^{* * *}$ & $0.193^{* * *}$ & $0.211^{* * *}$ \\
Age 55-64 & $(0.030)$ & $(0.031)$ & $(0.032)$ \\
& $0.182^{* * *}$ & $0.169^{* * *}$ & $0.190^{* * *}$ \\
Age 65+ & $(0.030)$ & $(0.031)$ & $(0.032)$ \\
& $0.074^{*}$ & 0.045 & 0.063 \\
Some College & $(0.043)$ & $(0.045)$ & $(0.046)$ \\
& $0.052^{*}$ & 0.026 & 0.023 \\
Bachelor's or More & $(0.028)$ & $(0.029)$ & $(0.030)$ \\
& $0.139^{* * *}$ & $0.096^{* * *}$ & $0.094^{* * *}$ \\
Married & $(0.029)$ & $(0.031)$ & $(0.032)$ \\
& $0.042^{* *}$ & $0.040^{*}$ & 0.024 \\
Employed & $(0.021)$ & $(0.021)$ & $(0.022)$ \\
& $0.068^{* * *}$ & $0.055^{* *}$ & $0.049^{*}$ \\
Retired & $(0.025)$ & $(0.025)$ & $(0.026)$ \\
& 0.036 & 0.034 & 0.024 \\
Household Income $>\$ 60,000$ & $(0.038)$ & $(0.039)$ & $(0.039)$ \\
& -0.006 & -0.022 & -0.035 \\
Financial Literacy Score & $(0.024)$ & $(0.024)$ & $(0.024)$ \\
& & $0.035^{* * *}$ & $0.028^{* * *}$ \\
Cognition Score & & $(0.009)$ & $(0.009)$ \\
& & & $0.030^{* *}$ \\
Observations & & & $(0.012)$ \\
& 2,075 & 1,990 & 1,874 \\
\hline
\end{tabular}

Probit average marginal effects with Delta Method robust standard errors in parentheses. $* * * \mathrm{p}<0.01,{ }^{* *}$ $\mathrm{p}<0.05, * \mathrm{p}<0.1$. 


\section{Appendix B - The Big Five Financial literacy questions in the NFCS (correct answer indicated in bold)}

\section{Interest Rate Question}

Suppose you had $\$ 100$ in a savings account and the interest rate was $2 \%$ per year. After 5 years, how much do you think you would have in the account if you left the money to grow?

More than $\$ 102$

Exactly $\$ 102$

Less than $\$ 102$

Do not know

Prefer not to say

\section{Inflation Question}

Imagine that the interest rate on your savings account was $1 \%$ per year and inflation was $2 \%$ per year. After 1 year, how much would you be able to buy with the money in this account?

More than today

Exactly the same

Less than today

Do not know

Prefer not to say

\section{Bond Price Question}

If interest rates rise, what will typically happen to bond prices?

They will rise

\section{They will fall}

They will stay the same

There is no relationship between bond prices and the interest rate

Do not know

Prefer not to say

\section{Mortgage Question}

A 15-year mortgage typically requires higher monthly payments than a 30-year mortgage, but the total interest paid over the life of the loan

will be less.

True

False 
Do not know
Prefer not to say

5. Risk Diversification Question

Please tell me whether this statement is true or false. "Buying a single company's stock usually provides a safer return than a stock mutual fund."

True

False

Do not know

Prefer not to say 


\section{Appendix C - Additional Regression Results}

Table A3: Full Set of Estimated Coefficients (I)

\begin{tabular}{|c|c|c|c|}
\hline $\begin{array}{c}\text { Explanatory Variables } \\
\text { in } 2012 \\
\end{array}$ & $\begin{array}{c}\text { Financially Satisfied } \\
\text { in } 2018 \\
\end{array}$ & $\begin{array}{c}\text { Can Meet } \$ 2,000 \\
\text { Shock in } 2018 \\
\end{array}$ & $\begin{array}{c}\text { Retirement Planning } \\
\text { in } 2018 \\
\end{array}$ \\
\hline Financial Literacy & $\begin{array}{c}0.131 * * \\
(0.067)\end{array}$ & $\begin{array}{c}0.047 * * * \\
(0.012)\end{array}$ & $\begin{array}{l}0.032 * \\
(0.017)\end{array}$ \\
\hline Female & $\begin{array}{c}0.100 \\
(0.135)\end{array}$ & $\begin{array}{l}-0.035 \\
(0.025)\end{array}$ & $\begin{array}{c}-0.058^{*} \\
(0.031)\end{array}$ \\
\hline White & $\begin{array}{c}0.362 * * \\
(0.167)\end{array}$ & $\begin{array}{c}0.084 * * \\
(0.033)\end{array}$ & $\begin{array}{c}0.055 \\
(0.042)\end{array}$ \\
\hline Age $33-44$ & $\begin{array}{c}0.303 \\
(0.234)\end{array}$ & $\begin{array}{l}-0.032 \\
(0.045)\end{array}$ & $\begin{array}{l}-0.046 \\
(0.054)\end{array}$ \\
\hline Age $35-54$ & $\begin{array}{l}0.388^{*} \\
(0.221)\end{array}$ & $\begin{array}{l}-0.013 \\
(0.043)\end{array}$ & $\begin{array}{l}-0.014 \\
(0.052)\end{array}$ \\
\hline Age 55-64 & $\begin{array}{c}0.774 * * * \\
(0.209)\end{array}$ & $\begin{array}{c}0.045 \\
(0.041)\end{array}$ & $\begin{array}{l}-0.019 \\
(0.050)\end{array}$ \\
\hline Age $65+$ & $\begin{array}{c}0.681 * * * \\
(0.253)\end{array}$ & $\begin{array}{c}0.049 \\
(0.054)\end{array}$ & $\begin{array}{l}-0.083 \\
(0.064)\end{array}$ \\
\hline Some College & $\begin{array}{c}0.098 \\
(0.217)\end{array}$ & $\begin{array}{c}-0.006 \\
(0.038)\end{array}$ & $\begin{array}{l}-0.014 \\
(0.049)\end{array}$ \\
\hline Bachelor's or More & $\begin{array}{c}0.299 \\
(0.220)\end{array}$ & $\begin{array}{c}0.056 \\
(0.040)\end{array}$ & $\begin{array}{c}0.061 \\
(0.051)\end{array}$ \\
\hline Married & $\begin{array}{c}0.036 \\
(0.143)\end{array}$ & $\begin{array}{l}-0.029 \\
(0.027)\end{array}$ & $\begin{array}{c}0.050 \\
(0.033)\end{array}$ \\
\hline Employed & $\begin{array}{l}0.375^{*} \\
(0.192)\end{array}$ & $\begin{array}{c}0.085^{* *} \\
(0.034)\end{array}$ & $\begin{array}{c}0.104 \\
(0.076)\end{array}$ \\
\hline Retired & $\begin{array}{c}1.065^{* * *} \\
(0.237)\end{array}$ & $\begin{array}{c}0.146^{* * *} \\
(0.047)\end{array}$ & $\begin{array}{c}0.110 \\
(0.080)\end{array}$ \\
\hline Income $>\$ 60,000$ & $\begin{array}{c}0.370^{* *} \\
(0.161)\end{array}$ & $\begin{array}{c}0.149 * * * \\
(0.031)\end{array}$ & $\begin{array}{c}0.074 * * \\
(0.035)\end{array}$ \\
\hline Cognition Score & $\begin{array}{c}0.020 \\
(0.085)\end{array}$ & $\begin{array}{l}0.026^{*} \\
(0.015)\end{array}$ & $\begin{array}{c}0.026 \\
(0.017)\end{array}$ \\
\hline Risk Aversion & $\begin{array}{l}-0.070 \\
(0.132)\end{array}$ & $\begin{array}{l}-0.013 \\
(0.025)\end{array}$ & $\begin{array}{c}-0.068 * * \\
(0.032)\end{array}$ \\
\hline Planning Attitude & $\begin{array}{l}-0.000 \\
(0.072)\end{array}$ & $\begin{array}{c}0.004 \\
(0.013)\end{array}$ & $\begin{array}{c}0.023 \\
(0.015)\end{array}$ \\
\hline Dep. Variable & $\begin{array}{c}0.478 * * * \\
(0.030)\end{array}$ & $\begin{array}{c}0.365^{* * * *} \\
(0.031)\end{array}$ & $\begin{array}{c}0.394 * * * \\
(0.035)\end{array}$ \\
\hline Constant & $\begin{array}{c}1.485 * * * \\
(0.446)\end{array}$ & $\begin{array}{c}0.010 \\
(0.077)\end{array}$ & $\begin{array}{c}-0.008 \\
(0.121)\end{array}$ \\
\hline Observations & 1,094 & 1,094 & 848 \\
\hline
\end{tabular}


Table A4: Full Set of Estimated Coefficients (II)

\begin{tabular}{|c|c|c|c|}
\hline $\begin{array}{c}\text { Explanatory Variables } \\
\text { in } 2012 \\
\end{array}$ & $\begin{array}{l}\text { Too Much Debt } \\
\text { in } 2018 \\
\end{array}$ & $\begin{array}{l}\text { Use of AFS } \\
\text { in } 2018 \\
\end{array}$ & $\begin{array}{l}\text { Bad Credit Card } \\
\text { Behavior in } 2018 \\
\end{array}$ \\
\hline Financial Literacy & $\begin{array}{l}-0.078 \\
(0.064)\end{array}$ & $\begin{array}{c}0.005 \\
(0.011)\end{array}$ & $\begin{array}{c}0.006 \\
(0.015)\end{array}$ \\
\hline Female & $\begin{array}{l}-0.039 \\
(0.124)\end{array}$ & $\begin{array}{c}-0.043 * * \\
(0.020)\end{array}$ & $\begin{array}{c}0.031 \\
(0.028)\end{array}$ \\
\hline White & $\begin{array}{l}-0.181 \\
(0.156)\end{array}$ & $\begin{array}{l}-0.053^{*} \\
(0.028)\end{array}$ & $\begin{array}{c}-0.084 * * \\
(0.041)\end{array}$ \\
\hline Age $33-44$ & $\begin{array}{c}-0.483 * * \\
(0.229)\end{array}$ & $\begin{array}{l}-0.013 \\
(0.038)\end{array}$ & $\begin{array}{l}-0.036 \\
(0.058)\end{array}$ \\
\hline Age $35-54$ & $\begin{array}{l}-0.497 * * \\
(0.208)\end{array}$ & $\begin{array}{l}-0.020 \\
(0.035)\end{array}$ & $\begin{array}{c}-0.115^{* *} \\
(0.053)\end{array}$ \\
\hline Age 55-64 & $\begin{array}{l}-1.132 * * * \\
(0.201)\end{array}$ & $\begin{array}{l}-0.016 \\
(0.034)\end{array}$ & $\begin{array}{l}-0.118 * * \\
(0.050)\end{array}$ \\
\hline Age $65+$ & $\begin{array}{l}-1.168^{* * *} \\
(0.250)\end{array}$ & $\begin{array}{l}-0.053 \\
(0.040)\end{array}$ & $\begin{array}{l}-0.078 \\
(0.061)\end{array}$ \\
\hline Some College & $\begin{array}{c}0.013 \\
(0.193)\end{array}$ & $\begin{array}{c}0.010 \\
(0.032)\end{array}$ & $\begin{array}{c}-0.106^{* *} \\
(0.045)\end{array}$ \\
\hline Bachelor's or More & $\begin{array}{l}-0.219 \\
(0.196)\end{array}$ & $\begin{array}{l}-0.007 \\
(0.033)\end{array}$ & $\begin{array}{c}-0.125^{* * *} \\
(0.046)\end{array}$ \\
\hline Married & $\begin{array}{c}0.023 \\
(0.131)\end{array}$ & $\begin{array}{l}-0.018 \\
(0.022)\end{array}$ & $\begin{array}{l}-0.011 \\
(0.032)\end{array}$ \\
\hline Employed & $\begin{array}{l}-0.035 \\
(0.173)\end{array}$ & $\begin{array}{l}-0.052 * \\
(0.029)\end{array}$ & $\begin{array}{l}-0.021 \\
(0.046)\end{array}$ \\
\hline Retired & $\begin{array}{c}-0.490 * * \\
(0.221)\end{array}$ & $\begin{array}{c}-0.087 * * \\
(0.037)\end{array}$ & $\begin{array}{c}-0.127 * * \\
(0.052)\end{array}$ \\
\hline Income $>\$ 60,000$ & $\begin{array}{c}-0.473 * * * \\
(0.141)\end{array}$ & $\begin{array}{c}-0.054 * * \\
(0.022)\end{array}$ & $\begin{array}{l}-0.032 \\
(0.031)\end{array}$ \\
\hline Cognition Score & $\begin{array}{l}0.172 * * \\
(0.068)\end{array}$ & $\begin{array}{c}-0.033 * * * \\
(0.012)\end{array}$ & $\begin{array}{l}-0.033^{*} \\
(0.018)\end{array}$ \\
\hline Risk Aversion & $\begin{array}{l}-0.166 \\
(0.121)\end{array}$ & $\begin{array}{c}0.016 \\
(0.019)\end{array}$ & $\begin{array}{l}-0.010 \\
(0.028)\end{array}$ \\
\hline Planning Attitude & $\begin{array}{c}0.051 \\
(0.061)\end{array}$ & $\begin{array}{c}0.001 \\
(0.010)\end{array}$ & $\begin{array}{l}-0.017 \\
(0.014)\end{array}$ \\
\hline Dep. Variable & $\begin{array}{c}0.416^{* * *} \\
(0.029)\end{array}$ & $\begin{array}{c}0.313 * * * \\
(0.038)\end{array}$ & $\begin{array}{c}0.386 * * * \\
(0.035)\end{array}$ \\
\hline Constant & $\begin{array}{c}3.338 * * * \\
(0.435)\end{array}$ & $\begin{array}{c}0.226 * * * \\
(0.070)\end{array}$ & $\begin{array}{c}0.510 * * * \\
(0.109)\end{array}$ \\
\hline Observations & 1,094 & 1,094 & 875 \\
\hline
\end{tabular}

